\title{
Effects of Pueraria tuberosa Linn Hydroalcoholic Tuber Extract on Expression of Apoptosis Associated Proteins in HT - 29 Human Colon Carcinoma Cell Line
}

\author{
M.R. Aruna ${ }^{1}$, D.J. Mukesh Kumar², P. Palani ${ }^{2}$, D. Senbagam ${ }^{3}$ and B. Senthilkumar ${ }^{\text {* }}$ \\ ${ }^{1}$ Department of Biotechnology, Muthayammal College of Arts and Science, \\ Rasipuram, TN, India \\ ${ }^{2}$ CAS in Botany, University of Madras, Guindy Campus, Chennai, TN, India \\ ${ }^{3}$ Department of Microbiology, Vivekananda College of Arts and Science for Women, \\ Tiruchengode, TN, India \\ *Corresponding author
}

\section{A B S T R A C T}

\section{Keywords}

Indian Kudzu,

Pueraria tuberose,

HT - 29,

Anticancer,

Apoptosis, Cell

cycle

Article Info

Accepted:

30 May 2018

Available Online:

10 June 2018
Medicinal plants have been used as an excellent source for years together as an alternative medicine for treating various disorders including anticancer, cardiovascular disorders and immunological disorders. Pueraria tuberose linn (PT) commonly known as Indian Kudzu is a folklore medicine used in Ayurvedic formulations against various disorders. The present study reports the anticancer potential of the hydroalcoholic tuber extract of PT which is rich in isoflavones. The cytotoxicity of PT tuber extract was evaluated by MTT assay. Further the apoptotic potential of the extract was confirmed by Ethidium bromide/acridine orange (EtBr/AO) staining assay. DNA fragmentation which is considered as the hallmark of apoptosis was also evaluated for the hydroalcoholic tuber extract of PT. The cellular DNA was stained and the distribution of cells in the sub-G1, G0/G1, S and G2/M phases were assessed by flow cytometry. The extract showed a $50 \%$ inhibition of cell viability against HT-29 cells at a concentration of $63.91 \mu \mathrm{g} / \mathrm{mL}$. HT-29 cells exhibited apoptotic cell death, increased the expression of caspases, p53 and Bax. Altogether, the results suggest that the hydroalcoholic PT tuber extract has a better anticancer activity against the tested human colon carcinoma cell line.

\section{Introduction}

Over the past few decades, there has been tremendous progress in our understanding of the molecular biology of cancer. Nonetheless, we have not conquered this dread disease yet. Like the majority of other human disorders, cancer is basically preventable. One of the most promising approaches to reduce the risk of cancer is chemoprevention (Greenwald, 2001; Kelloff et al., 2000).Chemo prevention is the attempt to use natural and synthetic compounds to intervene in the early precancerous stages of carcinogenesis, before malignancy manifests. Recently, there have been considerable efforts to search for naturally occurring substances for the intervention of carcinogenesis (Surh, 2003). 
To date, some phytomedicines have been postulated to be potential cancer chemo preventive agents through their ability to prevent, inhibit or reverse carcinogenesis. This ability is attributed to the presence of phytomedicines of specific families including polyphenols, polysaccharides, terpenes and sulfur compounds, which may be the possible reason for the anticancer mechanism.

Pueraria tuberosa commonly known as Indian kudzu is climber with woody tuberculated stem (Chopra, 1956), growing throughout tropical parts of India, mostly in moist regions. The plant constitutes major chemical constituents including isoflavone like daidzein, genistein, puerarin, puerarone, coumestan, tuberosin, pterocarpin tuberosin, puetuberosanol and hydroxyl tuberosone (Pandey et al, 1998). The tuberous root of PT is brown in color and slightly curved is used for rejuvenation treatment. The tubers of PT are described as sweet, refrigerant, emollient, laxative, aphrodisiac, galactogogue, diuretic, emetic, cardiotonic, expectorant, febrifuge and used for the treatment of various ailments (Devaiah, 2008). Moreover, it is also useful in emaciation of children, debility and poor digestion (Chopra, 1956; Vaidyaratnam, 1997). Its crude powder, ethanolic and butanolic extracts possess significant estrogenic activity as well as progestational and mild antiprogestational activity (Prakash et al., 1985). The antimicrobial activity effects of PT extracts from the tuber, leaf and root showed special attention towards hospital infection (Sadguna et al., 2015).

Antioxidant and anti - inflammatory activity of the tubers of PT and its active component puerarin was also reported recently (Pandey et al., 2007, Nidhi., 2010). Protection against stress induced myocardial ischemia by PT was also evaluated and it was the first clinical case to report cardio protective potential of PT tuber extract by its clinical improvement in angina and cardiac performance as well as favourable alterations in biochemical parameters without any untoward side effects (Verma., 2009).

Although the crude tuber extract of PT has been reported for various disorders such as hypoglycemic, antioxidant, cardioprotective, neuroprotective, anti - inflammatory and antiprogestational no study have reported concerning the anticancer activity of tuber extract of PT against human colon carcinoma. Hence the present study is an attempt to explore the anticancer potential of tuber extract of PT since it has already been proven a good antioxidant.

\section{Materials and Methods}

Rosewell Park Memorial Institute (RPMI) 1640 medium Dimethyl sulfoxide (DMSO), penicillin, streptomycin, tryspin-EDTA, MTT (3-(4,5-dimethylthiazol-2-yl)-2,5-diphenyl tetrazolium bromide). Fetal bovine serum (FBS) was obtained from GIBCO BRL (Gaithersburg, MD). Bcl-2, Bax, procaspase3 , cleaved caspase-3 and caspase - 9 were purchased from Cell Signaling Technology (Beverly, MA). $\beta$-actin and HRP-conjugated secondary antibodies were purchased from Santa Cruz Biotechnology (Santa Cruz, CA). All other chemicals were of analytical grade.

\section{Cell culture and drug preparations}

The Human Colon Adenocarcinoma cell lines (HT-29) were purchased from National centre for cell sciences (NCCS) Pune. Cells were maintained in RPMI 1640 medium (GIBCO BRL) supplemented with heat inactivated $10 \%$ fetal bovine serum (GIBCO BRL) and $2 \mathrm{mM}$ L-glutamine (Sigma Chemical Co), 100 units $/ \mathrm{ml}$ penicillin and $100 \mu \mathrm{g} / \mathrm{ml}$ streptomycin and maintained at $37^{\circ} \mathrm{C}$ in a atmosphere of $5 \% \mathrm{CO}_{2}$ incubator at $95 \%$ air humidified. 


\section{Cell proliferation assay or MTT assay}

Proliferation of HT - 29 cells was assessed by MTT assay (Safadi et al., 2003). The proliferation test is based on the colour reaction of mitochondrial dehydrogenase in living cells by MTT. Cells were plated in 96well plate at a concentration of $5 \times 10^{4}$ cells/well $24 \mathrm{~h}$ after plating. After $24 \mathrm{~h}$ of cells incubation, the medium was replaced with $100 \mu \mathrm{l}$ hydroalcoholic extract containing medium at different concentrations $(2-$ $1024 \mu \mathrm{g} /$ well) and incubated for $24 \mathrm{~h}$. Untreated cells served as control and received only $0.1 \%$ DMSO in which the fraction was prepared. At the end of treatment period, media from control and extract -treated cells was discarded and $20 \mu \mathrm{l}$ of MTT $(5 \mathrm{mg} / \mathrm{ml}$ PBS) was added to each well. Cells were then incubated for $4 \mathrm{~h}$ at $37^{\circ} \mathrm{C}$ in $\mathrm{CO}_{2}$ incubator. MTT was then discarded and the coloured crystals of produced formazan were dissolved in $200 \mu \mathrm{l}$ of DMSO and mixed effectively by pipetting up and down. Spectrophotometrical absorbance of the purple blue formazan dye was measured using an ELISA reader (BIORAD) at $570 \mathrm{~nm}$. Optical density of each sample was compared with control optical density and graphs were plotted.

\section{Ethidium bromide/acridine orange (Dual staining)}

Ethidium bromide/acridine orange staining was carried out by the method of Gohelet al., 1999. HT - 29 cells were plated at a density of $1 \times 10^{4}$ in 48 -well plates. They were allowed to grow at $37^{\circ} \mathrm{C}$ in a humidified $\mathrm{CO}_{2}$ incubator until they were $70-80 \%$ confluent. Then cells were treated with $64 \mu \mathrm{g} / \mathrm{ml}$ and $128 \mu \mathrm{g} / \mathrm{ml}$ (selected based on the $\mathrm{IC}_{50}$ concentration) of hydroalcoholic PT extract for $24 \mathrm{~h}$. The culture medium was aspirated from each well and cells were gently rinsed twice with PBS at room temperature. Then equal volumes of cells from control and drug treated were mixed with $100 \mu$ l of dye mixture (1:1) of ethidium bromide and acridine orange) and viewed immediately under Nikon inverted fluorescence microscope ( $\mathrm{Ti}$ series) at 10x magnification. A minimum of 300 cells was counted in each sample at two different fields. The percentage of apoptotic cells was determined by $[\%$ of apoptotic cells $=$ (total number of apoptotic cells/total number of cells counted) $\times 100$ ].

\section{DNA fragmentation assay}

DNA extraction and agarose gel electrophoresis were performed using the following method. Briefly, $1 \times 10^{6}$ cells were plated in 100-mm Petri dishes with DMEM containing $10 \%$ FBS. Cells were incubated for $24 \mathrm{~h}$ in5\% $\mathrm{CO}_{2}$ and $95 \%$ air at $37^{\circ} \mathrm{C}$. Control cells received0.1\% DMSO containing DMEM and PT extract -treated cells received 50 and $75 \mu \mathrm{g} / \mathrm{ml}$ of PT extract -containing DMEM. After $24 \mathrm{~h}$, the cells were trypsinized and combined with the cells in the medium by centrifugation at 1500 r.p.m. for $5 \mathrm{~min}$, and then they were washed twice with PBS. The resulting pellet was resuspended in $0.25 \mathrm{mlof}$ lysis buffer, transferred to a microfuge tube, and incubated for $1 \mathrm{~h}$ at $37^{\circ} \mathrm{C}$. To this $4 \mu \mathrm{l}$ of proteinase $\mathrm{K}$ was added and tubes were then incubated at $50^{\circ} \mathrm{C}$ for $3 \mathrm{~h}$. To each tube, $0.5 \mathrm{ml}$ of phenol: chloroform: isoamylalcohol (25:24:1) was added, mixed and centrifuged at 13000 r.p.m. for $30 \mathrm{~min}$ at $4^{\circ} \mathrm{C}$ to separate the DNA containing upper aqueous phase. To the resultant aqueous phase, two volumes of icecold absolute ethanol and 1/10the volume of 3Msodium acetate were added and kept at $20^{\circ} \mathrm{C}$ overnight to precipitate DNA. The DNA was pelleted by centrifuging at 13000r.p.m.for $10 \mathrm{~min}$ at $4^{\circ} \mathrm{Cand}$ the supernatant was aspirated and the pellet washed in $1 \mathrm{ml}$ of $70 \%$ ethanol. After repeating the above centrifugation step and removing last traces of the supernatant fraction, the pellet was allowed to dry at room temperature for approximately $30 \mathrm{~min}$ before being resuspended in $50 \mu$ lof Tris-EDTA buffer. 
DNA was quantified by ultraviolet visible spectroscopy and $10 \mu \mathrm{g}$ of DNA was electrophoresed in $1.5 \%$ agarose gel containing ethidium bromide in amini gel tank containing Tris-borate-EDTA buffer for 2 hat $90 \mathrm{~V}$. The gel was then examined under ultraviolet light and photographed.

\section{Flow cytometry}

Flow cytometric analysis was carried out as described by Rasola and Geuna (2001). Briefly, $1 \times 10^{6}$ cells were plated in $100-\mathrm{mm}$ Petri dishes with DMEM containing 10\% FBS. Cells were incubated for $24 \mathrm{~h}$ in $5 \% \mathrm{CO}_{2}$ and $95 \%$ air at $37^{\circ} \mathrm{C}$. Control cells received $0.1 \%$ dimethyl sulphoxide (DMSO) containing DMEM, and PT extract -treated cells received 50 and $75 \mu \mathrm{g} / \mathrm{ml}$ of PT extract containing DMEM. After $24 \mathrm{~h}$, the cells were trypsinized and combined with floating cells in the medium they were used for flowcytometry assay. The treatment protocol is as follows: $1 \times 10^{6}$ cells were taken from control and from PT extract treated plates and were centrifuged at 1000gfor $5 \mathrm{~min}$. Supernatant was removed and cells were washed twice with PBS. The pellet was resuspended in approximately $500 \mu$ of icecold PBS and cells were mixed by aspiration20 times using a pipette. Cells were fixed by adding $5 \mathrm{ml}$ of cold ethanol drop by drop and were kept at $-20^{\circ}$ Covernight. After overnight fixation, ethanol was removed by centrifuging at 1000 gfor $10 \mathrm{~min}$. The pellet was washed twice with PBS $+1 \%$ BSA (ethanol-fixed cells were difficult to pellet; adding BSA or serum to the wash medium overcame this). The pellet was resuspended in $800 \mu \mathrm{l}$ of PBS containing $1 \%$ BSA. One hundred micro litre of 10xpropidium iodide solution was added $(500 \mu \mathrm{g} / \mathrm{ml}$ propidium iodide in PBS, $\mathrm{pH}$ 7.4) and one hundred micro litre of RNase A was added $(10 \mathrm{mg} / \mathrm{ml}$ prepared in $10 \mathrm{~mm}$ Tris- $\mathrm{HCl}, \mathrm{pH}$ 7.5) and incubated at $37^{\circ} \mathrm{C}$ for $30 \mathrm{~min}$.

\section{Western blotting}

Western blotting was carried out as described previously (Tu et al., 2004). Briefly, HT-29 cells $\left(1 \times 10^{6}\right)$ were seeded onto $100-\mathrm{mm}$ culture dishes in the presence or absence of extract, and were treated for $24 \mathrm{~h}$. The medium was removed and the cells were washed with PBS (0.01M, pH7.2) for several times and lysed on ice in lysis buffer containing $100 \mu \mathrm{g} / \mathrm{ml}$ phenyl methyl sulfonyl fluoride (PMSF), $50 \mathrm{mM}$ Tris-base at $\mathrm{pH} 8.0,150 \mathrm{mM}$ $\mathrm{NaCl}, 0.02 \% \mathrm{NaN} 3,1 \% \mathrm{NP}-40$, and $1 \mu \mathrm{g} / \mathrm{ml}$ aprotinine. The supernatants were collected by centrifugation at $10,000 \times \mathrm{g}$ for $5 \mathrm{~min}$ at $4^{\circ} \mathrm{C}$, and were used as the cell protein extracts. The harvested protein concentration was measured using a protein assay kit (Bio-Rad). Equal amounts of total protein $(30 \mu \mathrm{g} /$ well $)$ were subjected to electrophoresed on $10 \%$ SDSpolyacrylamide gel and electro transferred onto PVDF membrane. Proteins were blocked overnight with $5 \%$ non-fat dried milk in PBS$\mathrm{T}$ at $2-8^{\circ} \mathrm{C}$. After washing in PBS containing $0.1 \%$ Tween 20 for 3 times, the membrane was incubated with the specific primary antibodies [Bcl-2 (rabbit polyclonal antibody at a dilution of 1:500), Bax (rabbit polyclonal antibody at a dilution of 1:500), procaspase-3 and cleaved caspase 3 (goat polyclonalantibody at a dilution of 1:250), and Caspase $9(1: 1000)]$ in 5\% (w/v) skim milk in PBST. After overnight incubation at $4^{\circ} \mathrm{C}$, the membrane was then washed three times with TBST, incubated further with alkaline phosphatase conjugated goat anti-mouse antibody, or anti-rabbit antibody at room temperature for 2 hours, and then washed three times with TBST. After reaction with horseradish peroxidase-conjugated goat antimouse antibody, the immune complexes were visualized by using the chemiluminescence ECL PLUS detection reagents following the manufacturer's procedure (Amersham Bioscience). 


\section{Statistical analysis}

Data were expressed as mean \pm S.E.M and analyzed by Tukey's testto determine the significance of differences between groups. A $p$ value lower than $0.05,0.01$ or/and 0.001 was considered to be significant.

\section{Results and Discussion}

Cytostatic effects of $\mathrm{Pt}$ hydroalcoholic extract against HT - 29 colon carcinoma cells

The in vitro cytotoxic effect of hydroalcoholic PT extract was screened against HT-29 cell line and viability of tumour cells was confirmed using MTT assay. The PT hydroalcoholic extract was able to reduce viability of the HT - 29 cells in a dosedependent manner as shown in (Figure 1). The $\mathrm{IC}_{50}$ value was found to be $63.91 \mu \mathrm{g}$.

\section{PT tuber extract induced apoptosis}

Acridine Orange/Ethidium Bromide (AO/EB) was done to evaluate the type of cell death induced by the PT extract in HT - 29cells; the morphological variations after double staining were investigated. Live cells stained with AO emitted green fluorescence. Early apoptotic cells had fragmented DNA which exhibited intense green coloured nuclei. Late apoptotic and necrotic cell's DNA were fragmented and stained orange and red. From the data it was clear that with increasing concentration of drug, the number of viable cells decreased tremendously. The percentage of apoptotic cells after treatment with $64 \mu \mathrm{g} / \mathrm{ml}$ and $128 \mu \mathrm{g} / \mathrm{ml}$ of drug was drastically increased $(p<0.001)$ to $37 \%$ and $66 \%$ respectively (Figure 2).

\section{DNA fragmentation}

Evaluation of apoptosis was further carried out by determining the DNA laddering as a result of DNA fragmentation, indicative of the late stage of apoptosis.DNA isolated from HT - 29 cells treated with PT extract showed evident fragmented DNA in a dose - dependent manner, when compared with control cells (Figure 3).

Extract of hydroalcoholic pt tuber inhibited cell cycle progression

The effect of the hydroalcoholic extract was studied on the cell cycle phases of the studied HT - 29 cells. After $24 \mathrm{~h}$ of incubation, stability in all the cell cycle populations is generally noticed and compared with the control cell line without treatment. Consistent with its effect on cell growth inhibition and induction of apoptosis, PT extract induced cell cycle arrest significantly arrested the cell growth at G2/M phase. PT extract treatment increased the cells in the sub G0/G1 phase from $0.18 \%$ to $22.59 \%$ in $64 \mu \mathrm{g}$ treated cells and $33.16 \%$ in $128 \mu \mathrm{g}$ treated cells respectively (Figure 4). An increased cell population in the sub G0/G1 phase with a concomitant decrease in the $\mathrm{G} 1$ and $\mathrm{S}$ phase compared to the untreated cells suggest that the PT tuber extract inhibited the cell cycle progression in G2/M phase and subjected the cells to apoptosis which is evident from cell accumulation in sub G0/G1 phase.

Alteration in Bax/Bcl 2 ratio, BID and activation of Caspase 9 and effector Caspases 3 and 8

Further the mechanism by which PT hydroalcoholic extract induced apoptosis was examined. Figure 5 demonstrates the protein analysis of Bax, Bid, Bcl2, Bid, Caspase 3, Caspase 8 and Caspase 9, as assessed by western blotting and its corresponding densitometric analysis. It is evident from the protein expression studies that PT extract increased the expression of proapoptotic 
factors Bax, Bid, Caspase 3, Caspase 8 and Caspase 9 and a subsequent decrease in anti apoptotic protein $\mathrm{Bcl} 2$ was observed dose dependently (Figure 5).

Uncontrolled cellular growth, as a consequence of defectsin the cell cycle and apoptotic machinery, is responsible for the development of most cancers. Therefore, agents that can regulate the cell cycle and apoptosis may be useful in the management and therapy of tumors (McDonald et al., 2000;
Owa et al., 2001, Kotha Anilkumar et al., 2017). Natural products exerting diverse bioactivities and possessing unique structural properties are important sources for the development of novel anti-tumor drugs (Newman DJ et al., 2000). The present study aimed to determine the ability of P.tuberosa hydroalcoholic extract to induce apoptosis and to identify the related biochemical mechanisms in a human colon cancer HT-29 cell line.

Figure.1 Anticancer activity of hydroalcoholic PT extract - MTT assay

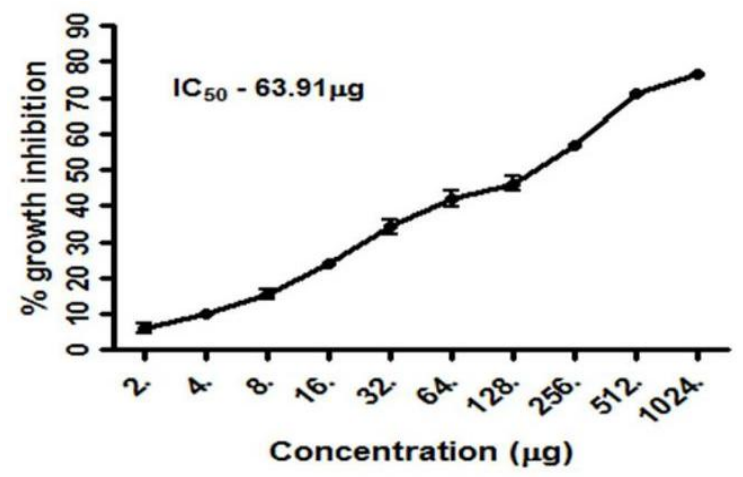

Values are expressed as Mean $\pm \operatorname{SEM}(n=3)$

Figure.2 Acridine Orange / Ethidium Bromide staining of HT-29 cells

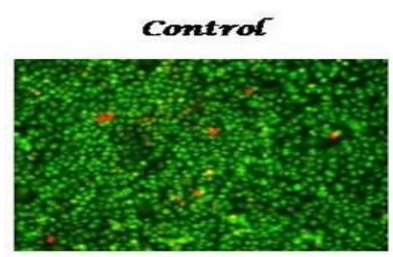

(A)

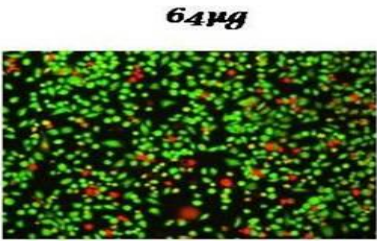

(B)

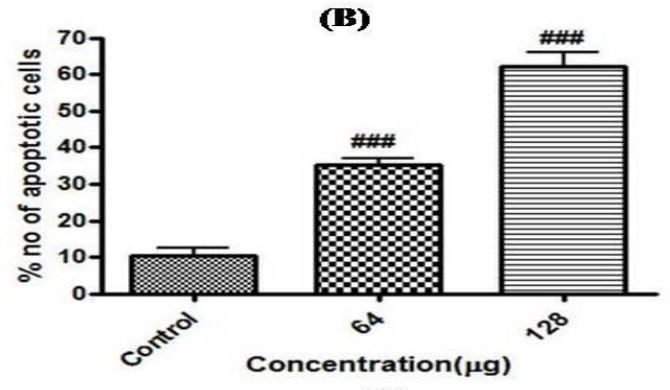

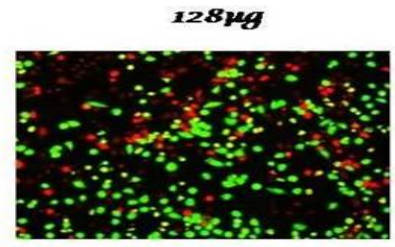

(C)

(D)

Morphological changes in the nuclei following hydroalcoholic PT extract induced apoptosis detected by $\mathrm{EtBr} / \mathrm{AO}$ staining. A: Negative control (without treatment). B \& C: Treatment with hydroalcoholic PT extract $64 \mu \mathrm{g}$ and $128 \mu \mathrm{g}$ respectively for $24 \mathrm{~h}$. D depicts representative bar graph of percentage number of apoptotic cells counted in three different fields. 
Figure.3 DNA fragmentation assay of HT-29 cells treated with hydroalcoholic PT extract

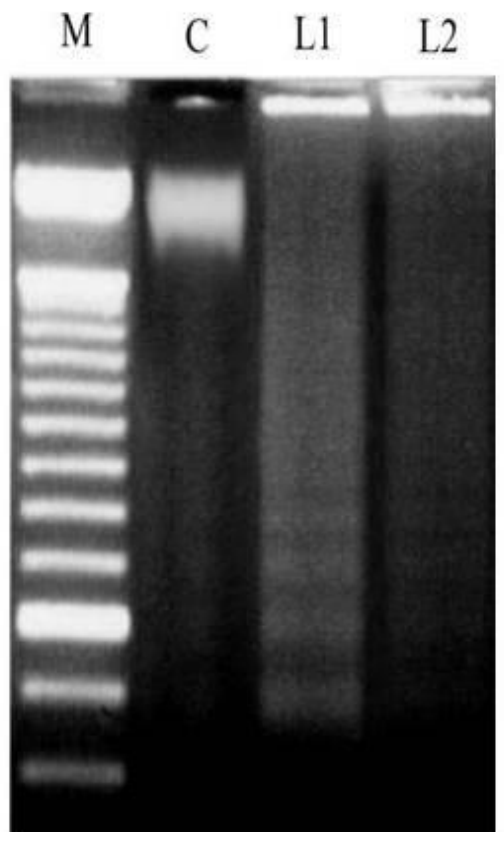

The isolated DNA was loaded into a well on a $2 \%$ agarose gel and electrophoresed. M refers to the 100 bp DNA marker

Figure.4 HT-29 cells DNA fragmentation during apoptosis by flow cytometry treated with hydroalcoholic PT extract

(A)
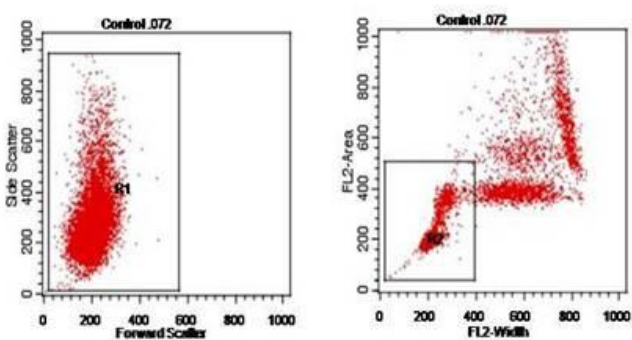

Contoilit-290n

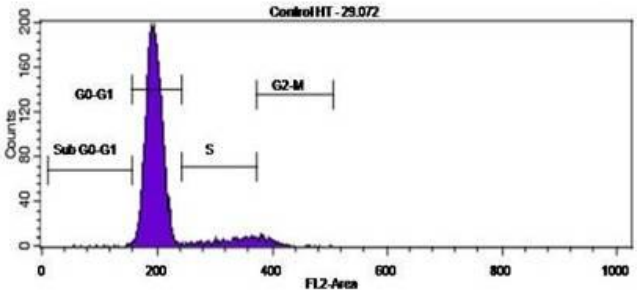

(B)
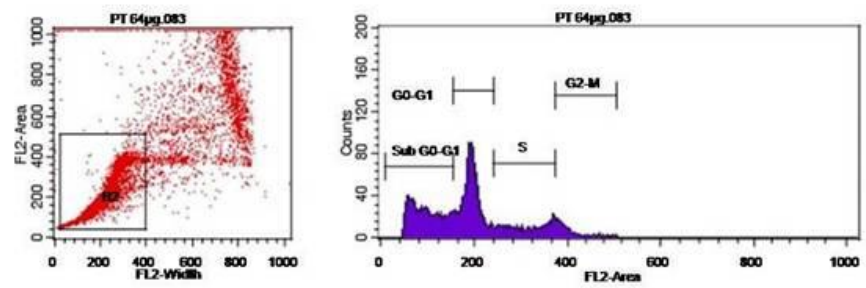

(C)
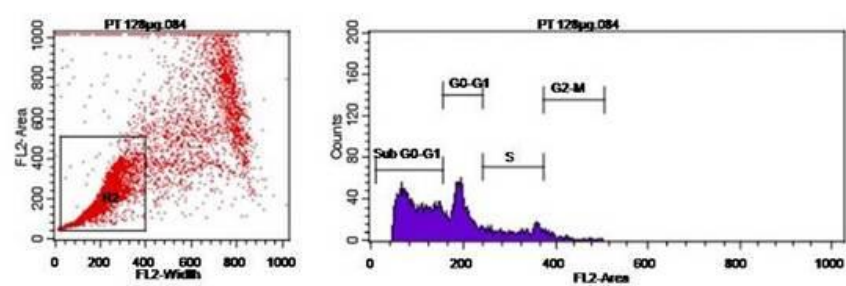

Control Cell, B \& C. PT extract treatment increased the cells in the sub G0/G1 phase from $0.18 \%$ to $22.59 \%$ in $64 \mu \mathrm{g}$ treated cells and $33.16 \%$ in $128 \mu \mathrm{g}$ treated cells respectively 
Figure.5 Effect of hydroalcoholic PT extract induced apoptosis in Caspase dependent pathway markers by immunoblotting analysis

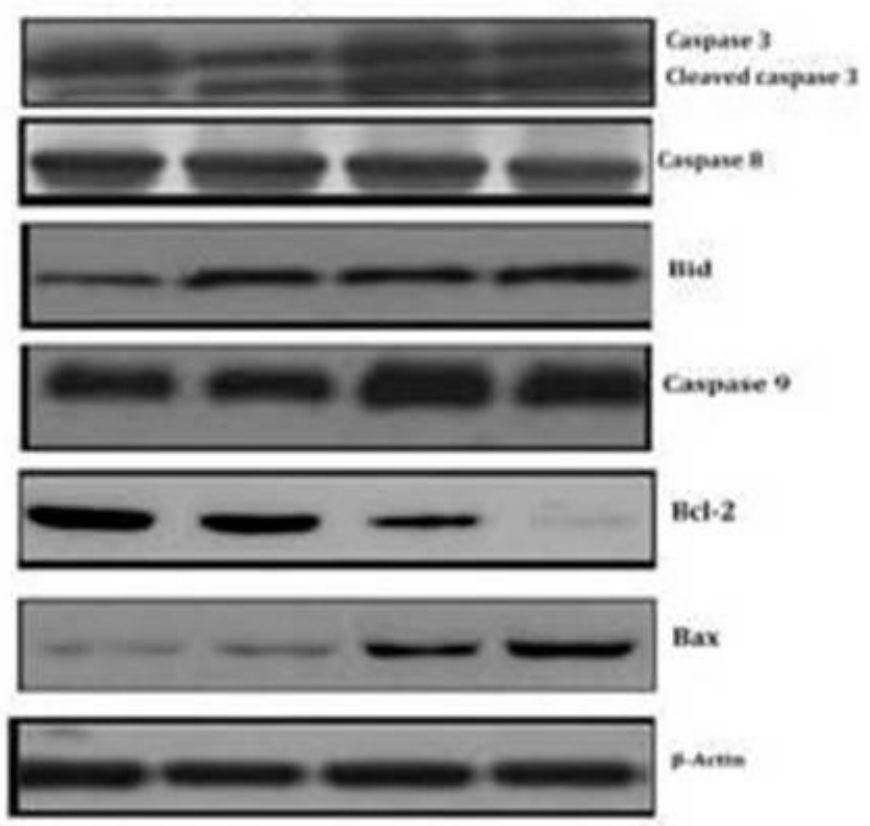

PT extract increased the expression of proapoptotic factors Bax, Bid, Caspase 3, Caspase 8 and Caspase 9 and a subsequent decrease in anti - apoptotic protein Bcl2

The present study showed that PT hydro alcoholic extract exhibited strong anticancer activity on HT - 29 human colon cancer cells via inhibition of proliferation and induction of apoptosis, which was dose - dependent with an $\mathrm{IC}_{50}$ value of $63.91 \mu \mathrm{g} / \mathrm{ml}$. The induction of apoptosis was confirmed by Etbr/AO staining procedure which showed that apoptosis percentage for $64 \mu \mathrm{g} / \mathrm{ml}$ and $128 \mu \mathrm{g} / \mathrm{ml}$ of drug was drastically increased $(\mathrm{p}<0.001)$ to $37 \%$ and $66 \%$ respectively. Also PT hydroalcoholic treatment resulted in apoptosis, as evidenced by specific shearing of DNA, which is considered to be the hallmark of apoptosis. Cell cycle arrest at G2/M phase with subsequent accumulation of cells at subG0 phase further confirms the apoptotic potential of PT hydroalcoholic tuber extract. Puerarin was also found to inhibit proliferation and induces apoptosis in human glioblastoma cell lines (Yang et al., 2015).
Apoptosis is initiated by a cascade of proteases known as caspases and these have become potentially attractive targets for the development of new cancer therapies. Two pathways of caspase activation have been described. The first one is mediated by death receptors, controlled by caspases $8 / 10$ and the second one is the mitochondrial mediated pathway and one of the primary regulators of this pathway to apoptosis is the family of Bcl2 proteins (Green and Reed 1998).In addition, caspase- 8 activated by apoptotic stimuli, converts Bid to truncated Bid (tBid), leading to conformational changes in Bax, mitochondrial depolarization, and cytochrome c release from mitochondria. This leads finally to the activation of caspase- 3 and induction of apoptosis via a complex of apoptotic protease activating factor-1 (Apaf1 ), pro-caspase-9, and cytochrome c after translocation of tBid to the mitochondria (S. 
Fulda et al., 2006). Thus, translocation of proapoptotic Bax proteins from cytosol to mitochondria represents a key event for the activation of apoptosis. To clarify the mechanisms of induction of apoptosis by PT hydroalcoholic extract, we investigated the expression of apoptosis-inhibiting and apoptosis-promoting proteins in HT - 29 cells. In the present study, quercetin induced a strong expression of Bax and tBid proteins, on the other hand, the level of expressions of Bcl-2 decreased in a dose dependent manner. The findings of the present investigation were found to be similar to the study conducted by Gan and Yin, (2015).

Death receptors (DRs) of the tumor necrosis factor receptor super family contain a conserved "death domain" in their intracellular region (Locksley et al., 2001). Fas associates with adaptor molecules, Fas Associated protein with Death Domain (FADD), through homotypic death domain interaction (Chinnayan et al., 1995). FADD then recruits caspase- 8 through homotypic interactions of death effector domains (DEDs), leading to caspase- 8 activation and induce apoptosis (Boldin et al., 1996). In the present study caspase- 8 expression was significantly increased in both $64 \mu \mathrm{g} / \mathrm{ml}$ and $128 \mu \mathrm{g} / \mathrm{ml}$ treatment respectively. Therefore, PT hydroalcoholic extract induces the activation of extrinsic pathway which is confirmed by the expression of caspase-8.

The PT extract induced apoptosis is a kind of caspase-3DNA fragmentation. Caspase-3 has been shown to play important role in chemotherapy (Ibrado et al., 1996). Activation of caspase- 3 appears to be a critical event in the execution of neuronal apoptosis (Honarpour et al., 2000). In the intrinsic pathway an apoptosis some complex is formed by Apaf-1, caspase-9, and cytochrome $\mathrm{C}$ as a result caspase-9 is activated which in turn activates caspase3.dependent and caspase- 3 activation is an upstream of The data further confirms that extrinsic pathways have contributed to PT hydroalcoholic extract induced apoptosis of HT-29 cells, as evident by increased expression of fragmented caspase-3, and -9 which was caused by caspase-dependent cell death and antigrowth inhibition activity for various types of human cancer cells was considered (Yukiko ey al., 2018).

Therefore the results in the present study concludes that PT hydroalcoholic extract possess potent anticancer property that induces apoptosis by activating caspase cascade pathway on human colon cancer HT 29 cell line. Thus it may be concluded that PT hydroalcoholic extract acts as a potential drug to induce apoptosis through the activation of caspases and other apoptotic related proteins.

\section{References}

Boldin MP, Goncharov TM, Goltsev YV, Wallach D., 1996. Involvement of $\mathrm{MACH}$, a novel MORT1/FADDinteractingprotease, in Fas/APO-1and TNF receptor-induced cell death.Cell 85:803-815.

Chandramohan KVP, Gunasekaran P, Varalakshmi E, Hara Y,Nagini S., 2007. In vitro evaluation of the anticancer effect of lactoferrin and tea polyphenol combination on oral carcinoma cells.Cell Biol. Int. 31, 599-608.

Chinnaiyan AM, O'Rourke K, Tewari M, Dixit VM.,1995. FADD, a novel death domain-containing protein, interacts withthe death domain of Fas and initiates apoptosis. Cell 81:505-512

Chopra RN, Nayar SL, Chopra IC.,1956. Glossary of Indian Medicinal Plants. CISR New Delhi, 256.

Devaiah KM, Venkatasubramanian P., 2008. Development of SCAR markers for authentication of Puerariatuberosa 
(Roxb. ex Willd.) DC. CurrSci; 94:1306-9.

Fulda S., K.M. Debatin,.2006. Extrinsic versus intrinsic apoptosis pathways in anti- cancer chemotherapy, Oncogene $254798-4811$.

Gan M, Yin X., 2015. Puerarin Induced in Mantle Cell Lymphoma Apoptosis and its Possible Mechanisms Involving Multi-signaling Pathway. Cell Biochem Biophys, 71: 367-73.

V. Sadguna, K. Sarikha, T. Raj Komuraiah and Md. Mustafa., 2015. Antimicrobial Activity of Pueraria tuberosa DC, an Economically and Medicinally Important Plant. Int.J.Curr.Microbiol.App.Sci.: $\quad 4(5)$ : 152-159.

Gohel A, McCarthy MB, Gronowicz G., 1999. Estrogen prevents glucocorticoid-induced apoptosis in osteoblasts in vivo and in vitro.Endocrinology140, 5339-5347.

Greenwald P.,2001. From carcinogenesis to clinical interventions for cancer prevention.Toxicology 166, 37-45.

Green DR, Reed JC,. 1998. Mitochondria and apoptosis. Science281:1309-1312. doi:10.1126/science.281.5381.1309.

Honarpour N, Du C, Richardson JA, Hammer RE, Wang X, HerzJ.,2000. Adult Apaf-1-deficient mice exhibit male infertility. DevBiol 218:248-258.

Ibrado AM, Huang Y, Fang G, Liu L, Bhalla K,.1996. Overexpression of bcl-2 or bcl-XL inhibits ARA-c induced cpp31/yamaprotease activity and apoptosis of human acute myelogenousleukemia hl-60 cells. Cancer Res 56:4743-4748.

Kelloff G. J., Crowell J. A., V. E. Steele, R. A. Lubet, W. A. Malone, C. W. Boone,L. Kopelovich, E. T. Hawk, R. Lieberman, J. A. Lawrence., 2000. Progress in cancerchemoprevention: development of diet-derived chemopreventive agents. J Nutr $130,467 \mathrm{~S}-471 \mathrm{~S}$

Kotha Anilkumar, Gorla V. Reddy, Rajaram Azad,. 2017. Evaluation of AntiInflammatory Properties of Isoorientin Isolated from Tubers of Pueraria tuberosa, Oxidative Medicine and Cellular Longevity, vol. 2017, Article ID 5498054, 10 pages https://doi.org/10.1155/2017/5498054.

Locksley RM, Killeen N, Lenardo MJ,.2001. The TNF and TNFreceptor superfamilies: integrating mammalian biology. Cell104:487-501

McDonald ER, El-Deiry WS.,2000. Cell cycle control as a basis for cancer drug development. Int J Oncol., 16:871-86.

Newman DJ, Cragg GM, Snader KM., 2000. The influence of natural products upon drug discovery. Nat Prod Rep;17:21534.

NidhiPandey, Yamini B Tripathi., 2010. Antioxidant activity of tuberosin isolated from Pueraria tuberose Linn. Journal of Inflammation, 7:47.

PandeyNidhi, Chaurasia JK, Tiwari OP, TripathiYamini B., 2007. Antioxidant properties of different fractions of tubers from Puerariatuberosa Linn. Food Chemistry FOCHMS 2007, 105:219-222.

Prakash, A.O., Saxena, V., Shukla, S. and Mathur, R., 1985. ActaEurFertil., 16: 59-65.

Pandey GS, Chunekar KC, Vidari K, (Eds)., 1998.

BhavPrakashNighantu.ChaukambhaVi dyaBhavan, Varanasi, 1:388-89.

Rasola A, Geuna M., 2001. A flow cytometry assay simultaneouslydetects independent apoptotic parameters. Cytometry 45, 151-157.

Safadi FF, Xu J, Smock SL, Kanaan RA, Selim AH, Odgren PR, Marks SC Jr, Owen TA, Popoff SN., 2003. 
Expression of connective tissue growth factor in bone: its role in osteoblast proliferation and differentiation in vitro and bone formation in vivo. J. Cell. Physiol.196, $51-62$.

Surh Y.-J., 2003. Cancer chemoprevention with dietary phytochemicals. Nature Rev Cancer3, 768-780.

Tu, L.C., Chou, C.K., Chen, C.Y., Chang, Y.T., Shen, Y.C., Yeh, S.F., 2004. Characterization of the cytotoxic mechanism of Mana-Hox, an analog of manzamine alkaloids. BiochimicaetBiophysicaActa 1672 (3), 148-156.

Vaidyaratnam P.S., 1997. Indian Medicinal Plants - A compendium of 500 species, Vol. 4, Orient longman publishing, Kottakkal: 391-395.

Verma S. K., V. Jain, A. Vyas and D. P.
Singh., 2009. Protection Against Stress Induced Myocardial Ischemia By Indian Kudzu (PuerariaTuberosa) - A CaseStudy. Journal of Herbal Medicine and Toxicology 3 (1) 59-63. Yang J-A, Li J-Q, Shao L-M, Yang Q, Liu BH, Wu T-F, Chen Q-X., 2015 Puerarin inhibits proliferation and induces apoptosis in human glioblastoma cell lines. Int J Clinical and Exp Med. 8(6): 10132-10142.

Yukiko Ogawa, Hiroko Murakami, Takuya Kuraoka, Ryukichi Mine and Hidemitsu Kobayashi. 2018. Specific Antiproliferative Activity against Several Human Cancer Cells Possessed by Cordyceps militaris Grown in Viable Pupa of Silkworm Raised under Sterile Environment. Int.J.Curr.Microbiol.App.Sci. 7(02): 988-997.

\section{How to cite this article:}

Aruna, M.R., D.J. Mukesh Kumar, P. Palani, D. Senbagam and Senthilkumar, B. 2018. Effects of Pueraria tuberosa Linn Hydroalcoholic Tuber Extract on Expression of Apoptosis Associated Proteins in HT - 29 Human Colon Carcinoma Cell Line. Int.J.Curr.Microbiol.App.Sci. 7(06): 3863-3873. doi: https://doi.org/10.20546/ijcmas.2018.706.455 